\title{
REGULATION OF BANK-OPERATED COLLECTIVE INVESTMENT FUNDS - JUDICIAL OR LEGISLATIVE RESOLUTION OF AN ADMINISTRATIVE CONTROVERSY?
}

Comptroller of the Currency James J. Saxon has recently stated:

... [N] either the Securities Act of 1933 nor the Investment Company Act of 1940 is, or should be applicable to the proposed collective investment funds. ${ }^{1}$

In reply, SEC Chairman William L. Cary counters :

We have taken the position that the banks are moving squarely into the mutual funds business and hence this new phase of expansion must be subject to the Investment Company Act of 1940 and the Securities Act. ${ }^{2}$

Thus, clearly drawn battle lines have emerged in the dispute between the Comptroller of the Currency and the SEC over the regulation of collective investment funds operated by banking institutions. Although banks have operated common trust funds for many years, these funds have never been the target of SEC attention. ${ }^{3}$ Generally, banks are not subject to SEC regulation and, in addition, the Investment Company Act specifically exempts common trust funds from its coverage. ${ }^{4}$ Recently, however, banks have received from the Comptroller authorization to commingle funds for collective investment on a much broader scale than in the past. ${ }^{5}$ It is in this new area of bank activity that the SEC is asserting its statutory obligation to apply both the Securities Act of $1933^{6}$ and Investment Company Act of 1940.7

The common trust fund was developed as a vehicle for the administration of small trusts in the late 1920's. ${ }^{8}$ Basically, the common trust is a pool of small trusts operated by a bank for the collective investment of funds held by the bank as trustee. ${ }^{\circ}$ While most banks find it unprofitable to administer small trusts on an individual basis, the common trust fund device allows banks to reduce administrative costs through the combination of individual trusts into a single entity for investment purposes. The beneficiary of the small trust thus

1. Hearing on Common Trust Funds - Overlapping Responsibility and Conflict in Regulation Before a Subcommittee of the House Committee on Government Operations, 88th Cong., 1st Sess. 162 (1963) [hereinafter cited as 1963 Heariung].

2. N.Y. Times, Dec. 5, 1963, p. 69, col. 6.

3. See 1963 Hearing 4.

4. Investment Company Act $\S 3$ (c) (3), 54 Stat. 789 (1940), 15 U.S.C. \$ 80a-3(c) (3) (1958).

5. Compare 27 Fed. Reg. 9767 (1962) (former $\$ 9.17$ governing bank collective investment), with 12 C.F.R. $\$ 9.18$ (Supp. 1964) (the revised regulation).

6. 48 Stat. 74 (1933), 15 U.S.C. $\$ \S 77 a-77 a a(1958)$.

7. 54 Stat. $789(1940), 15$ U.S.C. $\$ \$ 80 \mathrm{a}-1$ to $80 \mathrm{a}-52$ (1958).

8. For a summary of the development of common trust funds, see SEC, Report on Commingled or Common Trust Funds Administered by Banks and Trust Companies, H.R. Doc. No. 476, 76th Cong., 2d Sess. 406 (1939); Stephenson, Participating Investments - The Common Trust Fund Device, 12 Оніо Sт. L.J. 522, 523-27 (1951) ; Wolfe, Wider Horizons for Conmon Trust Funds, 101 TRUst \& Estates 1075 (1962).

9. See 3 Scotr, Trusts $\$ 227.9$, at 1683 (2d ed. 1956). 
gains the advantages of professional trust guidance and investment diversification at a relatively low unit cost. ${ }^{10}$ The initial development of the common trust was temporarily halted in 1936 by a federal court decision which held that common trust funds were subject to a separate tax as a corporation. ${ }^{11}$ Statutory relief from this tax burden was speedy. A provision of the Revenue Act of $1936^{12}$ - which now appears as section 584 of the Internal Revenue Code $^{13}$ - exempted common trust funds from taxation if they were maintained by a bank:

(1) exclusively for the investment and reinvestment of monies contributed thereto by the bank in its capacity as a trustee executor, administrator, or guardian; and (2) in conformity with the rules and regulations, prevailing from time to time, of the Board of Governors of the Federal Reserve System pertaining to the collective investment of trust funds by national banks. ${ }^{14}$

In 1937 the Federal Reserve Board, in order to satisfy the requirements of this provision, revised Regulation $F$ to provide rules for the operation of common trust funds. ${ }^{15}$ The most important limitation on the use of the collective investment funds imposed by the Board was the requirement that only funds held for a "bona fide fiduciary purpose" could participate in a common trust fund. ${ }^{10}$ The Board consistently emphasized that common trust funds were to be a tool in trust administration and not a medium for the investment of funds in the absence of traditional trust purposes. In 1940 the Board declared that the

trust guise or form should not be used to enable a trust institution to operate a Common Trust Fund as an investment trust attracting money seeking investment alone and to embark upon what would be in effect the sale of participations in a Common Trust Fund as investments. ${ }^{17}$

10. At first common trust fund participation was limited to trusts in which the settlor or testator authorized such participation in the trust instrument. This caution was dictated by common law prohibitions against commingling the funds of a trust with other funds held by the trustee. This and other common law objections to the use of common trust funds have been overcome in practically every American jurisdiction by enabling statutes which authorize use of the common trust fund device, even in the absence of specific instructions by the grantor. See 3 Scotr, Trusts $\$ 227.9$ (2d ed. 1956).

11. Brooklyn Trust Co. v. Commissioner, 80 F.2d 865 (2d Cir.), cert. denied, 298 U.S. 659 (1936).

12. 49 Stat. 1648 (1936).

13. INT. Rev. CoDE of $1954, \S 584$.

14. 49 Stat. 1648 (1936). In 1962 the words "or the Comptroller of the Currency" were inserted after "Federal Reserve System." 76 Stat. 670 (1962). In that year the Comptroller was given authority to issue rules governing collective investment by national banks. See notes 24-27 infra and accompanying text.

15. 2 Fed. Reg. 2976 (1937). Regulation F contained the Board's rules for the conduct of fiduciary activities by national banks. Prior to 1937 it did not make any provision for the operation of common trust funds.

16. Ibid. The bona fide fiduciary purpose requirement was understood to mean that to qualify a trust must have some raison d'etre other than to obtain the collective investment services of the bank. See, e.g., 42 Fed. Reserve Bul. 228 (1956) ; 41 Fed. Reserve BuLl. 142 (1955).

17. 26 FED. RES. BULL. 393 (1940). 
In this posture common trust funds were specifically exempted from coverage of the Investment Company Act of 1940.18 The exemption was granted because both Regulation $F$ and the Internal Revenue Code insured that common trust funds could not be used solely as a device for collective investment. For this reason, the SEC has never sought to characterize common trust funds operated in compliance with Regulation $\mathrm{F}$ as investment companies subject to the act. ${ }^{10}$

In addition to trust services banks also hold property and funds of customers in various "agency" accounts. ${ }^{20}$ Among the agency relationships that banks commonly enter are those in which the bank only recommends changes in investments which must then be acted on by the customer and those in which the bank has authority to manage the investments without direction from the customer. ${ }^{21}$ While the term, "managing agency account," is commonly used to refer to both relationships, in the context of the controversy between the Comptroller and the SEC the term refers only to agreements where the bank has complete investment discretion. ${ }^{22}$ Under Regulation $F$ such agency accounts could not participate in the common trust fund since they lacked the bona fide fiduciary purpose necessary for commingling..23

In 1962 responsibility for promulgating regulations governing bank fiduciary powers was shifted by statute to the Comptroller of the Currency. ${ }^{24}$ Not long thereafter Regulation $F$ was significantly revised and now appears as Regulation 9.25 The most important changes made by Regulation 9 are the authorization for pooling of managing agency accounts ${ }^{26}$ and the corresponding deletion of the "bona fide fiduciary purpose" requirement from the Regulation. ${ }^{27}$ This allows the banks to invest collectively funds which customers contribute for the sole purpose of investment. The SEC insists these new activities are subject to securities regulation. The Comptroller is equally adamant in his declarations "that the SEC has no business in this area."28 The Comptroller's general position is that the "bona fide fiduciary purpose" clause of the Federal Reserve Board's Regulation $F$ was not dictated by statutory requirements and

18. 54 Stat. 798 (1940), 15 U.S.C. \& 80a-3 (c) (3) (1958).

19. See Statement of William L. Cary, Chairman, Securities and Exchange Commission, in 1963 Hearing 4.

20. The differences between trust and agency relationships are explained in 1 Scort, Trusts § 8 (2d ed. 1956). See also Restatement (Second), Trusts \& 8 (1959).

21. See 1 Scotr, Trusts $\$ 8.1$ (2d ed. 1956).

22. It is only for those accounts where the bank has complete investment discretion that the comptroller has authorized pooling. The pool arrangement is not feasible where the bank must not act except upon instructions from each customer.

23. Cf. 1963 Hearing 4, 41-42.

24. 76 Stat. 668 (1962), 12 U.S.C. § 92a (Supp. V, 1964).

25. 12 C.F.R. $\& 9$ (Supp. 1954). The revised regulation became effective April 5, 1963.

26. 12 C.F.R. \$ 9.18(a) (3) (Supp. 1964).

27. See Saxon, New Trust Regulations Proposed, 102 Trusts \& Estates 95 (1963).

28. Explanatory Remarks of James J. Saxon, Comptroller of the Currency, Upon Revision of Regulation 9, April 5, 1963 at p. 5. 
that his recent revision merely represents a more liberal policy towards otherwise permissible bank activity. ${ }^{29}$ Specifically, he maintains that "units of participation in such funds are not securities"; 30 even if they were, they would come under the exemption of the Securities Act for bank-issued securities, and the exemptions of the Investment Company Act for banks and for any bank-operated "common trust fund or similar fund." 31

The Securities Act of 1933 and the Investment Company Act of 1940 both attempt to protect investors against dishonest and unethical practices on the part of persons and corporations selling securities. The 1933 act demands disclosure of certain important information to prospective investors. ${ }^{32}$ The Investment Company Act includes similar requirements and provides for disclosure of additional information peculiarly appropriate in the case of investment companies. ${ }^{33}$ Beyond this the act provides for the active regulation of investment company management to further insure investor protection. Both acts govern the operation of investment companies. In analyzing whether managing agency accounts should also be so regulated, only the provisions of the Investment Company Act will be considered here, since the claims for exemption under the Securities Act are essentially the same. ${ }^{34}$

29. 110 Conc. Rec. 791 (daily ed. Jan. 22, 1964) (letter by the Comptroller to Senator Robertson).

30. Explanatory Remarks of James $\mathfrak{J}$. Saxon, Comptroller of the Currency, Upon Revision of Regulation 9, April 5, 1963 at p. 5.

31. 54 Stat. 798 (1940), 15 U.S.C. $\$ 80 a-3$ (c) (3) (1958).

32. The information includes financial statements of the issuer, disclosure of dealings between directors, officers and major stockholders on one hand and the issuer on the other, statements of classes of stock issued, voting and other rights of all stock and many other detailed facts. This information must be registered with the SEC and provided to each prospective investor. 48 Stat. 81,88 (1933), 15 U.S.C. $\$ \S 77 \mathrm{j}, 77 \mathrm{aa}$ (1958).

33. 54 Stat. 803 (1940), 15 U.S.C. $\$ 80 a-8$ (1958). For example, an investment company must disclose its intended policies with regard to issuance of senior securities, borrowing and lending money, concentration of investment in selected industries, and the company must also disclose the actual rate of portfolio turnover during the three years prior to registration.

34. For each act to apply there must be an issuance of securities. See notes 35-40 infra and accompanying text. The Securities Act exemption for bank issued securities, 48 Stat. 75 (1933), 15 U.S.C. $\$ 77$ (1958), is subject to the same analysis as the 1940 act's exemption for banks, 54 Stat. 798 (1940), 15 U.S.C. \& 80a-3(c) (3) (1958). However, the common trust fund exemption is peculiar to the 1940 act. Ibid. Such funds were not subject to the 1933 act because no public offering was involved. See 1963 Hearing 4. Since the success of the pooled accounts depends upon wide public participation, they could not operate without a public offering. See Smith, The Mass Trust Market, 99 Trusts \& Estates 182 (1960). Thus if the 1940 act applies so does the 1933 act.

One form of proposed bank collective investment, however, is admittedly exempt from the 1940 act. This is the retirement fund which complies with the recent Self-Employed Individuals Retirement Act, 76 Stat. 809 (1962). Basically the act allows the self employed taxpayer to put aside up to $10 \%$ of his income (not to exceed $\$ 2,500$ a year) into a retirement plan and deduct half the amount of the contribution from his gross income for tax purposes. INT. REv. CODE of 1954, \$§ 404(a) (1), 404(c). These plans are specifically exempted from the 1940 act. 54 Stat. 799 (1940), 15 U.S.C. § 80a-3(c)(13) (1958). Such plans would still be subject to the 1933 act if the broader pooled managing agency accounts are subject to both the Securities and Investment Company Acts. 
Because of the substantive terms of the Investment Company Act, unless the operation of pooled managing agency accounts involves the issuance of a "security," the 1940 Act cannot subject the banks to SEC regulatic... Spokesmen for the bankers' position insist that no securities are involved. They rely on the fact that no certificates of participation are to be issued to those who place funds with a bank for collective investment. ${ }^{35}$ The statutory definition of "security," identical in the 1933 and 1940 acts, ${ }^{36}$ lends support to this argument for it seems to define a security as a written certificate of interest in an investment venture. However, stressing the policy of investor protection embodied in the acts, and looking to the economic realities of each situation, courts have uniformly given broadest possible construction to the term "security." Thus the Supreme Court has defined "investment contract," included within the definition of "security" in the 1933 act, as: "a contract, transaction or scheme whereby a person invests his money in a common enterprise and is led is expect profits solely from the efforts of . . . a third party. . .."37 Other courts have followed this lead and have held that the existence of formal certificates is not a prerequisite to SEC regulation. ${ }^{38}$ Indeed, a recent case has held that an oral agreement between an investor and a promoter was a "security" within the meaning of the Securities Act. ${ }^{39}$ The controlling factor, then, is not the form, or even the existence, of a particular piece of paper. It is rather the substance of the scheme and the relationship of the parties that determine whether the transaction is within the scope of federal regulation.

35. 12 C.F.R. $\$ 9.18$ (b) (13) (Supp. 1964). Apparently this provision was included to insure that participations in common trust funds would not be treated as securities.

36. Both acts define "security" as

any note, stock, treasury stock, bond, debenture, evidence of indebtedness, certificate of interest or participation in any profit-sharing agreement, collateral trust certificate, preorganization certificate or subscription, transferable share, investment contract, voting-trust certificate, certificate of deposit for a security, fractional undivided interest in oil, gas, or other mineral rights, or, in general, any interest or instrument commonly known as a "security", or any certificate of interest or participation in, temporary or interim certificate for, receipt for, guarantee of, or warrant or right to subscribe to or purchase any of the foregoing.

48 Stat. 74 (1933), as amended, 15 U.S.C. $\$ 77 \mathrm{~b}(1)$ (1958); 54 Stat. 795 (1940), as amended, 15 U.S.C. $\$ 80 \mathrm{a}-2$ (35) (1958) (emphasis added).

37. SEC v. W. J. Howey Co., 328 U.S. 293, 298-99 (1946). Investors had purchased small tracts in citrus groves and most had also entered long term contracts under which the vendor was to cultivate the land. Even though the investors received warranty deeds and not certificates of participation, the Court held that the transactions involved issuance of securities.

38. See, e.g., Roe v. United States, 287 F.2d 435 (5th Cir. 1961); Woodward v. Wright, 266 F.2d 108 (10th Cir. 1959). Earlier cases also gave liberal construction to "security" in order to protect investors. See, e.g., Penfield Co. v. SEC, 143 F.2d 746 (9th Cir. 1944) ; SEC v. Universal Service Ass'n, 106 F.2d 232 (7th Cir. 1939), cert. denied, 308 U.S. 622 (1940).

39. SEC v. Addison, 194 F. Supp. 709 (N.D. Texas 1961). The cases construing the term "security" involved the application of the 1933 act. There is no reason to believe courts would read the term more strictly when the Investment Company Act is the basis for the lawsuit. 
Since there will be a written agreement between the bank and the customer outlining the bank's obligations and rights with respect to the deposited funds,, 0 it seems likely that a court would find that a "security" has been issued.

The Comptroller of the Currency, in arguing that the SEC has no power to regulate bank sponsorship of collective investment funds, also relies heavily upon the specific exemption for banks and common trust funds in the Investment Company Act. ${ }^{41}$ In support of this position, the Comptroller maintains that Regulation 9 does not open the way for a new form of banking activity, but merely provides a more satisfactory modus operandi for the conduct of a traditional banking function. He claims that there is no essential difference between common trust funds and pooled managing agency accounts. ${ }^{42}$

While it is true that the managing agency account is an established bank activity, it differs from trust activities in that its sole purpose is to provide the investment advisory services of the bank for the customer. In the parlance of old Regulation F, it lacks the "bona fide fiduciary purpose" found in the ordinary trust. Regulation 9 eliminates that language and attempts to assimilate agency accounts with the other trust functions of the bank. In introducing Regulation 9, Mr. Saxon stated that the fiduciary relationship in agency accounts emanates from the "power of attorney and investment discretion"43 conferred upon the bank by the customer. There are, however, two objections to an attempt to equate managing agency accounts with "formally designated" trusts on the basis of their common concern with a fiduciary relationship and investment control. First, the fiduciary relationship, arising from an entrustment of funds, does not distinguish managing agency accounts and common trusts from investment companies. The Investment Company Act was passed to combat abuses arising from similar entrustments of funds for investment purposes. The investor in the mutual fund gives the fund managers the same degree of control and investment discretion that the participant in a pooled account gives to his bank. The act itself recognizes some degree of fiduciary responsibility in investment companies by providing penalties for "gross abuse of trust." 44 The second objection is that trustmen themselves apparently do not equate the fiduciary duties which they bear in relation to formal trusts with their responsibilities as managing agents. ${ }^{45}$ This attitude was implicit in a recent announcement by the First National City Bank of New York. ${ }^{40}$ The

40. At present, wher a customer opens a managing agency account he signs a power of attorney form authorizing the bank to act at its own discretion in investing the customer's funds. A similar agreement is contemplated in the operation of pooled managing agency accounts. See 110 CoNG. REc. 791 (daily ed. Jan. 22, 1964) (letter from James J. Saxon, Comptroller of the Currency, to Senator Robertson).

41. 54 Stat. 798 (1940), 15 U.S.C. $\$ 80 a-3$ (c) (3) (1958).

42. 110 Cong. Rec. 791 (daily ed. Jan. 22, 1964).

43. Explanatory Remarks of James J. Saxon, Comptroller of the Currency, Upon Revision of Regulation 9, April 5, 1963 at p. 2.

44. 54 Stat. 84 (1940), 15 U.S.C. $\$ 80 \mathrm{a}-36$ (1958).

45. Nor should they. Professor Scott and the Restatement emphasize that managing agency accounts are not trusts. 1 Scotr, Trusts \& 8.1 (2d ed. 1956); REstATEMENT (SECOND), TRUSTs $\$ 8$, comment i (1959).

46. Wall Street Journal, Feb. 26, 1964, p. 1, col. 5. 
bank had planned to start a pooled managing agency account fund under Regulation 9. However, when a tax ruling reiterated that pooled funds must be held "in trust" to be treated as common trust funds under section 584 of the Internal Revenue Code, ${ }^{47}$ the bank cancelled inauguration of the fund. If the trust officers at First National City Bank felt there was no essential difference between trusts and managing agency accounts, this ruling should not have affected their plans.

Recently in an apparent effort to reinforce the claim of similarity between the managing agency account and the common trust fund, Regulation 9 was amended. 48 "Managing agent" was redefined as a relationship that "imposes upon the bank the fiduciary responsibilities imposed upon trustees under will or deed." 40 And, to qualify for collective investment, managing agency agreements must now expressly provide that the bank holds monies received "in trust." "60 If these changes were intended to permit banks to invest collectively only funds they hold as trustees, it would appear that the bona fide fiduciary purpose concept was reintroduced as a requirement of Regulation 9. Obviously this was not the intention of the Comptroller; all his previous efforts had been directed at eliminating that very concept from the regulation. The more probable interpretation of the amendment is that the Comptroller was attempting to create the illusion of a trust function to satisfy the requirements of the Internal Revenue Code and the 1940 act, ${ }^{51}$ while permitting banks to invest funds collectively even where no "bona fide fiduciary purpose" existed. But one must question whether the Comptroller can immunize pooled managing agency accounts from SEC regulation and qualify the accounts for favorable tax treatment merely by changing the labels in Regulation 9 which characterize the relationships existing between the banks and their customers. Despite these attempts to assimilate trusts and managing agency accounts, it appears that under the current Regulation 9 they are intended to have separate functions and for this reason should be considered as distinct banking activities.

The basic dissimilarity in function between trusts and agency accounts should preclude automatic exemption of pooled accounts as common trust funds under the Investment Company Act. The question also remains whether the general exemption for banks in the 1940 act encompasses the operation of such accounts. Never before have banks been authorized to pool funds held

47. Rev. Rul. 64-59, 1964 INt. Rev. Butl. No. 8, at 12.

48. 29 Fed. Reg. 1719 (1964).

49. Ibid.

50. Ibid.

51. The mere fact that a fund is a trust cannot exempt it from the Investment Company Act. Almost 25\% of 156 open-ended mutual funds which were the subject of the Wharton School Study were established as trusts. Wharton School of Finance and Commerce, A Study of Mutual Funds, H.R. REP. No. 2274, 87th Cong., 2d Sess. 6 (1962) [hereinafter cited as Wharton School Study]. Since these trusts are all subject to the act, something more than the trust relationship must be present in common trust funds that led Congress to exempt them from regulation. 
as managing agent; the pooled account was unknown in 1940. To determine whether these funds should be subject to SEC regulation under the Investment Company Act, it seems necessary to consider them in the context of the policies Congress intended to implement by its securities legislation.

An analogous development in the area of insurance illustrates the probable judicial approach to the problem of statutory construction raised by the pooled managing agency account. In SEC v. Variable Anmuity Life Ins. Co. ${ }^{\text {t2 }}$ the Supreme Court held that the sale of variable annuities was subject to the provisions of both the Securities Act and the Investment Company Act, despite specific exemptions for annuity contracts in the 1933 act and for insurance companies in the 1940 act. Variable annuities differ from fixed annuities in that the return to the annuitant during the payout period is not a pre-determined number of dollars, but is a proportionate share of a portfolio of equity securities ${ }^{53}$ created by the contributions of many annuitants. The fund is managed by the company issuing the annuity policy and the annuitant's return depends upon the skill of the company and fluctuations in the securities market. Like the pooled managing agency account, variable annuities were unknown when the securities legislation was passed. ${ }^{54}$ In reaching the conclusion that variable annuities were subject to regulation under both acts, the Court reasoned that as new forms of insurance evolve they must be tested by the concept of insurance which led Congress to create the exemptions in the securities legislation. ${ }^{55} \mathrm{Mr}$. Justice Douglas, writing the majority opinion, thus concluded that since the variable annuity placed the entire risk of market fluctuation on the annuitant, it did not fit the statutory conception of insurance. ${ }^{56} \mathrm{Mr}$. Justice Brennan, in his concurring opinion, emphasized that where an investor is threatened by the dangers against which the acts provide protection, that protection is not to be denied because when the acts were passed the promoters' range of activities did not present such dangers. In reference to the regulations of the 1940 act he said :

These controls may be largely irrelevant to traditional banks and insurance companies, which Congress clearly exempted; they were not investing heavily in equity securities and holding out the possibility of capital gains through fund management; but where the investor is asked to put his money in a scheme for managing it on an equity basis, it is evident that the Federal Act's controls become vital. ${ }^{57}$

Variable annuities then were held subject to SEC regulation because of their close similarity to the type of investment contracts which were the object of congressional concern in the securities legislation. Likewise the contemplated pooled managing agency accounts, although unknown in 1940, are essentially similar to the mutual fund; in both the investor's only purpose is to secure the benefits of collective investment - diversification and professional investment
52. 359 U.S. 65 (1959).
53. See $i d$. at 70.
54. Id. at 75 (concurring opinion).
55. Id. at 69 .
56. Id. at 71-73.
57. Id. at 79-80 (emphasis added). 
management. Investors in mutual funds receive the benefits and protections of the securities legislation, and it would seem that to effectuate the policies of the securities legislation courts should extend the protections of the act to similarly placed investors by holding pooled managing agency accounts subject to SEC regulation.

Reference to the legislative history of the 1940 act further strengthens this conclusion. The primary object of the 1940 act was to protect by regulation the large investment made by the public in puols of common stocks supervised by professional managers. 58 Included in the congressional concept of investment company were funds involving "an agency relationship between the individual contributors to the fund and the management upon whom they confer substantially a power of attorney to act as agent in the investment of the moneys contributed." the characteristics of such companies was their reliance upon widespread public participation. On the other hand, Congress seems to have envisaged the common trust fund in a wholly different manner; it was thought of solely as a tool for the administration of small trusts, not as a vehicle for public investment. ${ }^{60}$ An early draft of the Investment Company Act defined the common trust fund by reference to the Internal Revenue Act provision exempting such funds from taxation and thus incorporated the restrictions of Regulation $F$ limiting the use of common trust fund devices to trusts with a "bona fide fiduciary purpose."61 Similarly, the SEC report to Congress on the common trust fund emphasized the fact that the funds were subject to Regulation F.62 The report further pointed out that common trust funds did not advertise to or solicit the public investor. ${ }^{63}$ The SEC in its report to Congress concluded that the common trust fund was primarily a service device used to administer existing trusts. ${ }^{64}$ The clear thrust of the SEC reports was that the common trust fund did not conform to the congressional model of the investment company because of its lack of utility for large-scale public investment. Since the commercial feasibility of the pooled managing agency account depends upon relatively broad public participation, it seems to fit the congressional conception of an investment company and the common trust fund exemption of the 1940 act should not immunize it from regulation. For the same reason the act's exemption for banks ${ }^{65}$ should not apply to the managing agency account;

58. See Findings and Declaration of Policy, 54 Stat. 789 (1940), 15 U.S.C. \& 80a-1 (1958).

59. SEC, Report on Invesiment Trusts and Investment Companies, Part I, H.R. Doc. No. 707, 75th Cong., 3d Sess. 24 (1939).

60. See SEC, Report on Commingled or Common Trust Funds Administered by Banks and Trust Companies, H.R. Doc. No. 476, 76th Cong., 2d Sess. (1939).

61. Id. at 4-5.

62. SEC, Report on Commingled or Common Trust Funds Administered by Banks and Trust Companies, H.R. Doc. No. 476, 76th Cong., 2d Sess. 25 (1939). Regulation F is set out in its entirety in this report. $I d$. at 27 .

63. Id. at 6 .

64. SEC, Report on Investment Trusts and Investment Companies, Part I, H.R. Doc. No. 707, 75th Cong., 3d Sess. 33 (1939).

65. 54 Stat. 798 (1940), 15 U.S.C. $\S 80 a-3$ (c) (3) (1958). 
Congress could not have intended that the mere fact that a bank originated an investment company would operate to confer immunity. ${ }^{66}$

Although the statutory interpretation advanced should lead to regulation of the pooled managing agency account under the 1940 act, the courts will be faced with the argument that the pooled account is entitled to the bank exemption because it is merely one of a myriad of banking functions not susceptible to isolation as a separate activity. ${ }^{67}$ In answer to this contention the SEC argues that the real issuer of the securities is the pooled fund itself rather than the bank. ${ }^{68}$ Under this theory the managing agency account becomes an "investment company" subject to the 1940 act. This separate entity concept has recently received judicial approval in a case involving the sale of variable annuities by an established insurance company. In Prudential Insurance Co. $v$. $S E C^{69}$ the Third Circuit held that variable annuities offered by Prudential must comply with the provisions of the Investment Company Act.

While Prudential maintained that these annuities were offered by an insurance company and were thus exempt from the Investment Company Act, ${ }^{70}$ Judge Staley emphasized that broad construction must be given to securities legislation "to insure the investing public a full measure of protection."71 In order to give that needed protection the court held that the fund itself, not Prudential, was the issuer of the securities and was in fact an investment company under the 1940 act. $^{72}$ The rationale of Prudential seems to have equal applicability to banks, as well as insurance companies. If applied, a bank's pooled fund of managing agency accounts would be treated as a separate entity subjeot to SEC regulation under the 1940 act.

Although current securities law appears to place the pooled managing agency account under SEC regulation, Congress has recently been presented with an opportunity to reevaluate the existing regulatory scheme as it applies to bankoperated funds. Legislation has been proposed which would unequivocally exempt pooled accounts from the operation of the Securities Act and the Investment Company Act, and would place the managing agency account under the regulation of the Comptroller. The proposed bill, ${ }^{73}$ entitled the

66. Supporting this view is the consideration that the managing agency account, like the common trust fund, is substantially different from most bank activities. In the agency account the investor assumes the risk of market fluctuation; while depositors are presumably assured a fixed return: without risk to the sum invested.

67. The same argument is advanced for the contention that the securities issued under these plans are bank-issued securities and thus exempt from the Securities Act of 1933, 48 Stat. 76 (1933), 15 U.S.C. \& 77c(a) (2) (1958). This position is necessary if SmathersKeogh plans are to be exempt from SEC regulation completely, since such plans are admittedly exempt from the Investment Company Act. See note 34 supra. The separate entity theory of the Prudential case, 326 F.2d 383 (3d Cir. 1964), would apply equally here to conclude that the fund and not the bank is the issuer.

68. 1963 Hearing 4.

69. 326 F.2d 383 (3d Cir.), cert. denied, 84 Sup. Ct. 1629 (1964).

70. Id. at 385 .

71. Id. at 386 .

72. Id. at 388 .

73. S. 2223, H.R. 9410, 88th Cong., 1st Sess. (1963). 
Bank Collective Investment Fund Act, delegates to the Comptroller the responsibility of promulgating rules for the operation of pooled managing agency accounts and outlines the disclosure and reporting requirements he is to implement - essentially the provisions now in effect under Regulation 9.74 Those agencies which now supervise and examine the various state and national banks are charged with enforcement of the bill and the rules promulgated under it by the Comptroller. ${ }^{75}$ Violation of the bill or any regulation renders the bank liable to a fine. ${ }^{76}$

In stating his support for the legislation the Comptroller has denied that the proposed act will conflict with the policies of the existing laws, because under his control banks will not be permitted to enter the mutual fund market. ${ }^{77}$ Heavy reliance is placed upon the current restrictions on advertising pooled account plans ${ }^{78}$ and the provision of the proposed bill which would allow the Comptroller to continue this limitation.79 The bankers, however, appear to be preparing for a large-scale assault upon those investors who typically turn to mutual funds. Many articles have appeared exhorting the banking industry to ready itself for handling large numbers of small investors on an "assembly line" basis as commingled managing agency accounts draw this business away from mutual funds. ${ }^{80}$ The Comptroller may disclaim responsibility for such statements, ${ }^{81}$ but one must consider them in predicting what the banks will do under a blanket exemption from the securities laws. The current inhibition on advertisement of pooled agency accounts is not complete. Banks are permitted to let the public know they are operating a fund, although they cannot emphasize this service in their advertising. ${ }^{82}$ Some bankers regard

74. Id. \& 6 .

75. Id. $\S 8$.

76. Id. § 9 .

77. 110 Cong. Rec. 791-92 (daily ed. Jan. 22, 1964) (letter from James J. Saxon, Comptroller of the Currency, to Senator Robertson).

78. 12 C.F.R. $\$ 9.18(5)$ (iv) (Supp. 1964).

79. S. 2223, H.R. 9410, 88th Cong., 1st Sess., § 6(h) (1) (1963).

80. See, e.g., Smith, The Mass Trust Market, 99 TRusts \& Estates 182 (1960); Judd, Common Trust Funds Under Regulation 9, 102 TRusts \& Estates 569 (1963); address by G. T. Iumpkin; Jr., 44th Mid-Winter Trust Conference, Feb. 5, 1963, reprinted in 1963 Hearing i14.

81. 110 Conc. Rec. at 792 (daily ed. Jan. 22, 1964).

82. 12 C.F.R. \& 9.18(b) (5) (iv) (Supp. 1964) provides:

A copy of the financial report shall be furnished, or notice shall be given that a copy of such report is available and will be furnished without charge upon request, to each person to whom a regular periodic accounting would ordinarily be rendered with respect to each participating account. The report, in such summarized form as prescribed by the Comptroller of the Currency, shall be published in a newspaper of general circulation in the place where the principal office of the bank is located. In addition, a full report shall be furnished upon request to any person, and the fact of the availability of such material may be given publicity solely in connection with the promotion of the fiduciary services of the bank. Except as herein provided, the bank shall not advertise or publicize its collective investment funds. The cost of printing, publication and distribution of the report shall be borne by the bank. 
this restriction as a significant limitation on their ability to promote commingled funds, but most seem to believe that they can reach a large number of investors in spite of the control..$^{83}$

The Comptroller in support of the legislation also contends that the investor in a pooled agency account would receive better protection than his mutual fund counterpart, and he explicitly questions the efficacy, as applied to pooled accounts, of the regulatory scheme that has become engrained in our economy. ${ }^{84}$ If investor safeguards under the pending legislation would be at least comparable in effect to those under the securities legislation, it would be consistent with the general policy of investor protection expressed in the 1940 act to allow regulation by the Comptroller; this would seem true even if the banks do enter the mutual investment field in large numbers. In evaluating current regulation of mutual funds under the Investment Company Act, Congress has the benefit of an exhaustive study of fund operation prepared by the Wharton School of the University of Pennsylvania at the request of the SEC. ${ }^{85} \mathrm{Al}$ though this study has shown that many of the provisions of the Investment Company Act provide little actual protection to the investor, the SEC criticism of the proposed act is based largely upon its failure to include the very provisions which the Wharton School study revealed as ineffective throughout the 20-year history of the act. ${ }^{86}$

The Investment Company Act contains many provisions that find no counterpart in the proposed bill. One of the chief objectives of the act was to provide greater investor participation in the management of the fund ${ }^{87}$ in order to insure that the fund would be operated for the benefit of the investor and not for the fund's directors, officers and other managers. ${ }^{88}$ Accordingly, the act provides that the declared investment policy of the fund cannot be changed without shareholder consent. ${ }^{89}$ Shareholders must elect at least two-thirds of the directors, ${ }^{90}$ must approve the appointment of independent auditors ${ }^{91}$ and must ratify the investment advisory contract every two years. ${ }^{92}$ And to insure shareholder participation all mutual fund shares issued after the act became effective must be voting shares. ${ }^{93}$ Although the SEC cites the complete lack of investor participation as a major shortcoming of the pending bill, ${ }^{94}$ share-

83. Cf. authorities cited in note 80 supra. See also Bliss, Harris \& Bethel, Should Pooled Funds Be Permitted for Managing Agencies?, reprinted in 1963 Hearing at 121.

84. See mote 77 supra.

85. Wharton School Study.

86. 109 Cong. Rec. 23997 (daily ed. Dec. 19, 1963) (letter from SEC Chairman Cary to Senator Robertson).

87. See 10 SEC ANn. Rep. 162 (1944).

88. 54 Stat. 789 (1940), 15 U.S.C. $\& 80 a-1$ (1958) (declaration of policy).

89. 54 Stat. 811 (1940), 15 U.S.C. $\$ 80 a-13$ (1958).

90. 54 Stat. 813 (1940), 15 U.S.C. \$ 80a-16 (1958).

91. 54 Stat. 838 (1940), 15 U.S.C. \& 80a-15 (1958).

92. 54 Stat. 812 (1940), 15 U.S.C. $\$ 80 \mathrm{a}-15$ (1958).

93. 54 Stat. 821 (1940), 15 U.S.C. \$80a-18(i) (1958). Mutual Funds organized as common law trusts are exempted from this requirement. Ibid.

94. 1963 Hearing 12; 109 CoNg. Rec. 23999 (daily ed. Dec. 19, 1963). 
holder control is virtually non-existent in the mutual fund industry despite the elaborate voting provisions of the 1940 act. The Wharton School Study has disclosed that 90 per cent of open-ended mutual funds, comprising over 94 per cent of total net asset value, are controlled by managements that have less than 5 per cent interest in the fund. ${ }^{95}$ Year after year these same managements are approved by the shareholders who vote through management-controlled proxy machinery. ${ }^{\circ 6}$ Individual interests in the fund are so small and widely scattered that effective opposition to management proposals is a costly, and probably futile, undertaking. ${ }^{97}$ It is far easier for the dissatisfied shareholder to redeem his shares than to seek to effect any change in management policy. This condition, however, apparently is not a deterrent to investors who have little, if any, desire to exert control over the fund but who only seek the professional advice and diversification which the fund provides. ${ }^{98}$ Moreover, the 1940 act by its own terms also recognizes that shareholder voting is not indispensable for investor protection; funds organized as common law trusts before passage of the act were permitted to continue operation without giving investors full voting rights. ${ }^{99}$

The SEC in its criticism of the pending bill also points to the lack of a board of directors in the pooled agency account. ${ }^{100}$ This criticism is based on the second major requirement of the Investment Company Act - that at least forty percent of the board of directors cannot be persons affiliated with management. $^{101}$ The purpose of this limitation is ostensibly to provide an independent check on all major company decisions. However, since the term "affiliated person" is narrowly defined in the act, ${ }^{102}$ it loses much of its potential for investor protection. Relatives and close associates of the control group may serve as "independent" directors. The fact that these unaffiliated directors are proposed to the shareholders through the management-dominated proxy machinery and thus depend on management for their continued existence as directors further weakens this protection. ${ }^{103}$ Finally, boards of directors commonly are not the active force in operating the mutual fund; in many

95. Wharton School Study 7.

96. Id. at 66 .

97. See generally the discussion of control and distribution of mutual fund shares in the Wharton School Study at 52-73.

98. The Wharton School Study has aptly stated:

Since mutual fund shareholders are buyers of investment services as well as owners, and frequently regard the former as the more important aspect of their relationship with the mutual fund, the very concept of shareholder control through the exercise of voting rights may be contrary to the realities of the mutual fund business. . . . [M] anagement control has been a virtually automatic consequence of possession of the corporate proxy machinery by the promoting management group. Id. at 7-8.

99. 54 Stat. 814 (1940), 15 U.S.C. § 80a-16(b) (1958).

100. 109 Cong. Rec. 23999 (daily ed. Dec. 19, 1963).

101. 54 Stat. 806 (1940), 15 U.S.C. $\$ 80 a-10$ (a) (1958).

102. 54 Stat. 791 (1940), 15 U.S.C. $\$ 80 a-2$ (a) (3) (1958).

103. Wharton School Study 8. 
cases investment decisions are executed by the adviser without the necessity of board approval.104 The ineffectiveness of the board of directors may not be of great consequence when one views mutual funds as a medium through which the small investor seeks only to buy the services of the investment adviser. On the other hand, the existence of a seemingly "independent" board of directors which merely rubber-stamps the advisor's actions may give the investor a false sense of security, in that he may too readily assume that the advisor's actions have been subjected to independent scrutiny. Thus, viewed in the context of actual operation, the provisions for an independent board do not offer significant protection against possible over-reaching by the control group, and the lack of a board of directors with independent members in the agency account would not seem to deprive the investor of a meaningful protective device.

A third major complaint of the SEC is that the Bank Collective Investment Fund Act does not contain disclosure requirements adequate to permit investors to intelligently select a particular fund. ${ }^{\mathbf{1 0 5}}$ The bill calls for a written plan to be filed with the appropriate supervisory agency and kept available at the bank. ${ }^{106}$ The contents of the plan must include complete information as to manner of fund operation, investment policy, valuation of assets, conditions for admission and withdrawal, basis for termination of the fund and any other matters the Comptroller may prescribe. ${ }^{107} \mathrm{~A}$ copy of the plan together with a financial report, the contents of which are also prescribed by the act, must be furnished to each prospective investor. ${ }^{108}$ Because the plan and financial statement do not follow the same pattern as a prospectus, Chairman Cary insists that "the investor is not told what his rights in the fund are in an intelligible form." 109 It should be noted, however, that the normal securities prospectus is itself a technical document and the information which it contains is not set forth in simple terms readily understandable by the average investor. ${ }^{110}$ Since no plans for pooled managing agency accounts have as yet been inaugurated, it can only be hoped that the plans will be easier to understand than prospectuses issued under SEC supervision. Assuming, however, intelligible presentation of facts in the plan, the information called for seems adequate to allow informed investment choice.

According to the Wharton School Study the most effective protective device of the 1940 act is section $17^{111}$ which is aimed at self-dealing on the part of the management group ${ }^{112}$ by prohibiting certain transactions between the management group and the fund. Regulation 9, which presumably will be carried forward under the new bill, contains corresponding protections against

104. Ibid.

105. 109 Cong. Rec. 23999 (daily ed. Dec. 19, 1963) ; 1963 Hearing 10.

106. S.2223, H.R. 9410, 88th Cong., 1st Sess., § 6(c) (1963).

107. Id. $\& 6(\mathrm{~d})$.

108. Id. $\S 6(\mathrm{f})$.

109. 109 Cong. Rec. 23999 (daily ed. Dec. 19, 1963).

110. See generally 1 Loss, Securitres Regulation 178-261 (2d ed. 1961).

111. 54 Stat. 815 (1940), 15 U.S.C. $\$ 80 \mathrm{a}-17$ (1958).

112. Wharton School Study 35. 
self-dealing by banks which accept collective trusts. ${ }^{113}$ In fact, the Comptroller's regulation may provide broader protection than section 17 of the Investment Company Act. Section 17 only prohibits transactions between the fund and "affiliated persons," a technical term the impact of which might be easily diluted by narrow construction. ${ }^{111}$ The regulation, however, prohibits transactions between the collective investment fund and any "individuals with whom there exists such a connection, or organizations in which there exists such an interest, as might affect the exercise of the best judgment of the bank. . . ."115 Because its operation applies only to "affiliated persons" section 17 may have to be buttressed by other provisions of the act, such as section $35^{116}$ which authorizes the SEC to sue to enjoin gross abuses of trust; the Comptroller's regulation appears sufficiently broad in itself to provide an adequate basis for controlling any abuse of trust. One possible weakness of the current regulation is that the instrument creating the managing agency may authorize transactions which would otherwise be termed "self-dealing."117 An unsophisticated investor might not realize the potential for abuse that such a clause would inject into the agreement. More effective control over transactions that involve self-interest could be maintained if such general authorizations were prohibited, and if the Comptroller's office were empowered to grant exemptions in specific cases where investigation showed the investors' best interests were not compromised. 118

In addition to at least an equivalence of investor protection there are several reasons which militate strongly for passage of the Bank Collective Investment Act. First, the relatively simple regulatory scheme of the new bill, especially in comparison to the 1940 act, indicates probable ease of application with a corresponding savings in time, energy and administrative cost to both the regulatory agency and the regulated bank. Perhaps in recognition of the extensive and novel burdens entailed under SEC regulation, banks have not instituted any pooled managing agency accounts, and there is every indication that if the new bill is not passed, banks will not do so in the future. ${ }^{119}$ If this

113. 12 C.F.R. $\$ 9.12$ (Supp. 1964).

114. See notes 100-103 supra and accompanying text.

115. 12 C.F.R. $\$ 9.12$ (Supp. 1964).

116. 54 Stat. 841 (1940), 15 U.S.C. $\$ 80 a-35$ (1958).

117. Section 9.12 prohibits "self dealing" transactions "unless lawfully authorized by the instrument creating the relationship, or by court order or by local law . . ."12 C.F.R. \& 9.12 (Supp. 1964).

118. Such authority would be similar to that now possessed by the SEC under $\$ 17$ of the Investment Company Act. See note 111 supra.

An added protection under the Comptroller's regulation is the annual inspection of the fund by bank examiners. The SEC does not attempt to inspect each mutual fund every year. See 1963 Hearing 43.

119. If the Investment Company Act applies to the pooled accounts the banks will probably not be able to operate such funds economically. See H.R. REP. No. 429, 88th Cong., 2d Sess. 3 (1963). The bankers' chief concern in this area is to avoid SEC regulation. See, e.g., Saxon, New Trust Regulations Proposed, 102 Trusts \& Estates 95 (1963); Judd, Common Trust Funds Under Regulation 9, 102 TRUSTs \& Estates 569 (1963). 
is indeed the case, not only will the banks be deprived of a substantial area for future growth, but the investing public will suffer because of the large cost differential between the pooled account and most mutual funds. Under the 1940 act a mutual fund may charge the investor a sales load on up to nine per cent of all money invested to cover salesmen's commissions and promotion charges, in addition to the annual administrative charge imposed on all shareholders in the fund. ${ }^{\mathbf{1 2 0}}$ No loading charges can be imposed on investors in pooled managing agency accounts ${ }^{121}$ and the annual service charges may not exceed the fees which the bank could charge to administer a trust of identical size. ${ }^{122}$

In sum, it is possible for Congress to modify the application of the securities laws in this narrow area without detriment to its broad policy of investor protection. The Comptroller of the Currency has had almost thirty years of experience in regulating common trust funds. ${ }^{123}$ His regulation under the new act should provide protection at least comparable to that afforded to investors by the SEC, and can be applied efficiently within the framework of existing banking procedures. The proposed bill is, moreover, desirable because of the savings it may produce for the investor; competition between the pooled account and the mutual fund industry should also produce cost benefits to the public. The results of the Wharton School Study may prompt Congress to provide more effective regulation of the investment company industry. Until such time the simpler and apparently adequate scheme of Regulation 9 and the Bank Collective Investment Fund Act seems to be a better approach to supervision of bank-operated funds. ${ }^{124}$

120. 54 Stat. 829 (1940), 15 U.S.C. $\$ 80 a-27$ (a) (1) (1958). The sales load applics to periodic payment plans where the investor agrees to make monthly payments into the fund for a period of time, often ten years. This type of operation is contemplated for pooled managing agency accounts. See Smith, The Mass Trust Market, 99 TRUsts \& ESTATES 182 (1960).

121. See 1963 Hearing $80,83$.

122. 12 C.F.R. $\$ 9.18$ (b) (12) (Supp. 1964).

123. A consideration Congress should not overlook in deciding whether to allow the Comptroller to regulate these funds is the close affiliation of the Comptroller to banking interests. It may be argued that he cannot provide objective regulation in the investors' best interests because of his natural sympathy towards those he regulates. On the other hand the Comptroller's expertise in regulating bank activities may be wasted in this area if the SEC is chosen to regulate the pooled accounts. For discussion of this problem in another administrative agency see Huntington, The Marasmus of the ICC: The Commission, The Railroads, and the Public Interests, 61 YALE L.J. 467 (1952).

124. One apparent shortcoming of the Bank Collective Investment Fund Act is that, while it exempts managing agency accounts from securities legislation, it does not amend $\$ 584$ of the Internal Revenue Code to relieve them from being taxed as corporations. The recent ruling that deterred the First National City Bank from inaugurating a pooled fund indicates that the Internal Revenue Service is reluctant to extend the exemption to pooled managing agency accounts. The proposed act does not attempt to enlarge the fiduciary duties of banks sponsoring managing agency accounts by redesignating them as trustees rather than agents. Therefore, even if agency accounts were exempted from SEC regulation, the act's purpose might be frustrated, because they would fail to qualify for the exemption of $\$ 584$. Pooled managing agency accounts are not economically feasible unless the tax exemption applies. Therefore the act should include a provision amending $\S 584$ to include funds collectively invested by the bank in its capacity as managing agent. 